\title{
Individual Phenolics and Enzymatic Changes in Response to Regulated Deficit Irrigation of Extra-early Nectarines
}

\author{
Natalia Falagán and Francisco Artés \\ Postharvest and Refrigeration Group, Regional Campus of International Excellence Campus Mare \\ Nostrum, Universidad Politécnica de Cartagena, Paseo Alfonso XIII, 48, 30203 Cartagena, Murcia, \\ Spain; and Institute of Plant Biotechnology, Universidad Politécnica de Cartagena, Campus Muralla \\ del Mar, 30202 Cartagena, Murcia, Spain
}

\author{
Perla A. Gómez \\ Institute of Plant Biotechnology, Universidad Politécnica de Cartagena, Campus Muralla del Mar, \\ 30202 Cartagena, Murcia, Spain
}

Francisco Artés-Hernández

Postharvest and Refrigeration Group, Regional Campus of International Excellence Campus Mare Nostrum, Universidad Politécnica de Cartagena, Paseo Alfonso XIII, 48, 30203 Cartagena, Murcia, Spain; and Institute of Plant Biotechnology, Universidad Politécnica de Cartagena, Campus Muralla del Mar, 30202 Cartagena, Murcia, Spain

\begin{abstract}
Alejandro Pérez-Pastor and Jose M. de la Rosa
Soil-Water-Plant Group, Departamento de Producción Vegetal, Universidad Politécnica de Cartagena, Paseo Alfonso XIII, 48, 30203, Cartagena, Murcia, Spain

Encarna Aguayo ${ }^{1}$

Postharvest and Refrigeration Group, Regional Campus of International Excellence Campus Mare Nostrum, Universidad Politécnica de Cartagena, Paseo Alfonso XIII, 48, 30203 Cartagena, Murcia, Spain; and Institute of Plant Biotechnology, Universidad Politécnica de Cartagena, Campus Muralla del Mar, 30202 Cartagena, Murcia, Spain
\end{abstract}

\begin{abstract}
AdDitional INDEX wORDs. water stress, bioactive compounds, catalase, polyphenol oxidase, phenylalanine ammonia-lyase, ascorbate peroxidase

Abstract. The effect of long-term regulated deficit irrigation (RDI) strategies on bioactive compounds and enzymes at harvest, during cold storage $\left[0{ }^{\circ} \mathrm{C}, 90 \%\right.$ to $95 \%$ relative humidity $\left.(\mathrm{RH})\right]$ and after a simulated retail sale period $\left(15{ }^{\circ} \mathrm{C}\right.$, $\mathbf{7 0 \%}$ to $75 \% \mathrm{RH}$ ) of extra-early nectarine 'VioWhite 5' [Prunus persica (L.) Batsch] was evaluated for 3 consecutive years. RDI strategies were scheduled as follows: 1) control [irrigated at $110 \%$ of maximum crop evapotranspiration (ETc) during the whole season], 2) $\mathrm{RDI}_{1}$ (irrigated at $110 \%$ ETc during critical periods of growth and at $85 \%$ of control during the rest of the growing season), and 3) $\mathrm{RDI}_{2}$ (irrigated at $110 \%$ ETc during critical periods of growth and at $80 \%$ and $60 \%$ control during the second fruit growth stage in March and late postharvest, respectively). Results suggested the existence of water stress when RDI was applied on extra-early nectarine. The RDI effect induced a change on the activity of enzymes studied that depended on the intensity and duration of water stress. RDI fruit, especially $\mathrm{RDI}_{2}$, presented higher catalase (CAT), phenylalanine ammonia-lyase (PAL), and ascorbate peroxidase (APX) enzyme activity and, together with dehydroascorbic acid level, appeared as indicators of this abiotic stress. RDI nectarine fruit increased total phenolic and flavonoids contents improving the nutraceutical quality of the product. With storage, polyphenol oxidase (PPO) increased its activity through the reduction of flavonoids, particularly in pulp. In this study, $\mathrm{RDI}_{2}$ achieved the highest initial and stored antioxidant capacity values. Peel compared with pulp was the main tissue where bioactive compounds were found in 'VioWhite 5' nectarine fruit and the only tissue with anthocyanin content in this white pulp nectarine. The significant water savings were of 780 and $2050 \mathrm{~m}^{3} \cdot \mathrm{ha}^{-1} \mathrm{per} \mathrm{year}^{-1}$ for $R D I_{1}$ and $R D I_{2}$, respectively. RDI can be used as a field practice to enhance bioactive compounds on extra-early nectarine fruit and to contribute to reduce water demand.
\end{abstract}

Received for publication 9 Oct. 2015. Accepted for publication 26 Jan. 2016. We are grateful to the Ministry of Economy and Competitiveness-FEDER for financial support (project AGL2010-19201-C04-02-AGR and AGL201019201-C04-04) and for the concession of a predoctoral grant to N. Falagán. We also thank Frutas Esther S.L. for providing plant material and to Institute of Plant Biotechnology of the UPCT for the use of some equipment.

${ }^{1}$ Corresponding author. E-mail: encarna.aguayo@upct.es.
Nectarines and peaches (Prunus persica) are the fourth most important fruit crops in the world, and the second most important in Europe, after apple (Malus domestica Borkh.; Legua et al., 2012). Spain is the second leading European producer with 1 million tonnes per year and leading exporter to European markets (Iglesias, 2012). Peaches are indisputably the preferred summer fruit for consumers, expecting a high-quality 
nutritional and organoleptic product. Nutritionally, nectarine fruit contain phytochemical compounds such as polyphenols and carotenes (García-Parra et al., 2011) with high antioxidant potential. Previous studies have reported that an increase in the consumption of vegetables and fruit reduce the risk of diseases such as neck or head cancers (Maasland et al., 2015) and polyphenols such as chlorogenic acid, caffeic acid, or anthocyanins as cyanidin-3-glucoside found in peaches have a positive effect on the reduction in breast cancer incidence (Vizzotto et al., 2014) and other health-promoting benefits (Boeing et al., 2012).

In this work, the extra-early nectarine cultivar VioWhite 5 was selected, as it had the proper caliber and organoleptic characteristics for the European market. It is a clingstone cultivar with bright red peel and white flesh. Early cultivars fetch high market prices in northern Europe, but their characteristics require cultivation in areas with high temperatures and short winters as found in Mediterranean climates that face intense periods of drought. Furthermore, the impact of water scarcity in areas such as southern Europe is being intensified in recent years with climate change (Iglesias et al., 2007). In Mediterranean climates, agricultural systems are one of the leading water consumers, and improving irrigation management reduces strain on future water supplies (Katerji et al., 2008). One possible solution is the application of irrigation water below the total ETc requirements during certain phenological periods, known as RDI (Chalmers et al., 1981; Domínguez et al., 2012; Goldhamer, 1989). The design of these RDI strategies implies the study of crop responses to water stress while maintaining high-quality parameters in plants and products. Previous research has shown that application of RDI could even improve the quality of stone fruit such as in their skin color, increased soluble solids concentration improved fruit taste, reduced weight loss, and reduced fungal attacks during postharvest (Crisosto et al., 1994; Falagán et al., 2014; Mpelasoka et al., 2001; Pérez-Pastor et al., 2007). Water deficit promote and allow bioactive compounds concentration, as well as increasing antioxidant activity (CAT, APX, superoxide dismutase; Barbagallo et al., 2013; Laribi et al., 2013). Some studies link this accumulation of compounds to oxidative stress, which directly or indirectly influences the biosynthetic pathway of these compounds (Urban et al., 2014). The bioactive compounds, such as ascorbic acid (AsA), phenols, anthocyanins, flavonoids, and carotenoids are part of the plant's defense system, and many of them have human health-promoting effects, as mentioned.

In addition, it is important to note that extra-early cultivars are very compatible with RDI due to their major water requirements coincide with low ETc periods (Abrisqueta et al., 2010; Alcobendas et al., 2012). Furthermore, most RDI studies focus on tree status and fruit quality (Buendía et al., 2008; Sotiropoulos et al., 2010; Thakur and Singh, 2012), but the effect of water stress on the enzymatic activity of stone fruit has not been studied. The RDI effect on extra-early cultivars is still very limited, existing a lack of knowledge about the existence of water stress effect on fruit metabolism when RDI is applied. It is known the importance of oxidative stress in plant drought responses. This responses range oxidative damage to the role of reactive oxygen species (ROS) in signaling (de Carvalho, 2013; Miller et al., 2010; Noctor et al., 2014). This means that plants need to perceive a stimulus and transform into a signal that activates defense mechanisms to survive. It is therefore opportune to try to understand how the enzyme activity varies due to these signals activating bioactive
Table 1. Maturity parameters [soluble solids concentration (SSC), total titratable acidity, and maturity index] at harvest of 'Viowhite 5' nectarine fruit subjected to three different irrigation regimes $(n=3)$.

\begin{tabular}{|c|c|c|c|}
\hline \multirow{2}{*}{$\begin{array}{l}\text { Irrigation } \\
\text { regime }^{z}\end{array}$} & SSC (\%) & $\begin{array}{l}\text { Total acidity [citric } \\
\text { acid }(\mathrm{g} / 100 \mathrm{~mL})]\end{array}$ & $\begin{array}{c}\text { Maturity index } \\
\text { (SSC/acidity ratio) }\end{array}$ \\
\hline & \multicolumn{3}{|c|}{ Mean $\pm \mathrm{SE}$} \\
\hline Control & $9.15 \pm 0.12$ & $1.34 \pm 0.02$ & 0.07 \\
\hline $\mathrm{RDI}_{1}$ & $10.05 \pm 0.05$ & $1.19 \pm 0.01$ & $8.66 \pm 0.20$ \\
\hline $\mathrm{RDI}_{2}$ & $10.30 \pm 0.24$ & $1.23 \pm 0.01$ & $8.24 \pm 0.14$ \\
\hline
\end{tabular}

${ }^{\mathrm{z}}$ Control $=$ irrigated at $110 \%$ of maximum crop evapotranspiration (ETc) during the whole season, $\mathrm{RDI}_{1}=$ irrigated at $110 \%$ ETc during critical periods of growth and at $85 \%$ of control during the rest of the growing season, $\mathrm{RDI}_{2}=$ irrigated at $110 \%$ ETc during critical periods of growth and at $80 \%$ and $60 \%$ control during the second fruit growth stage in March and late postharvest, respectively.

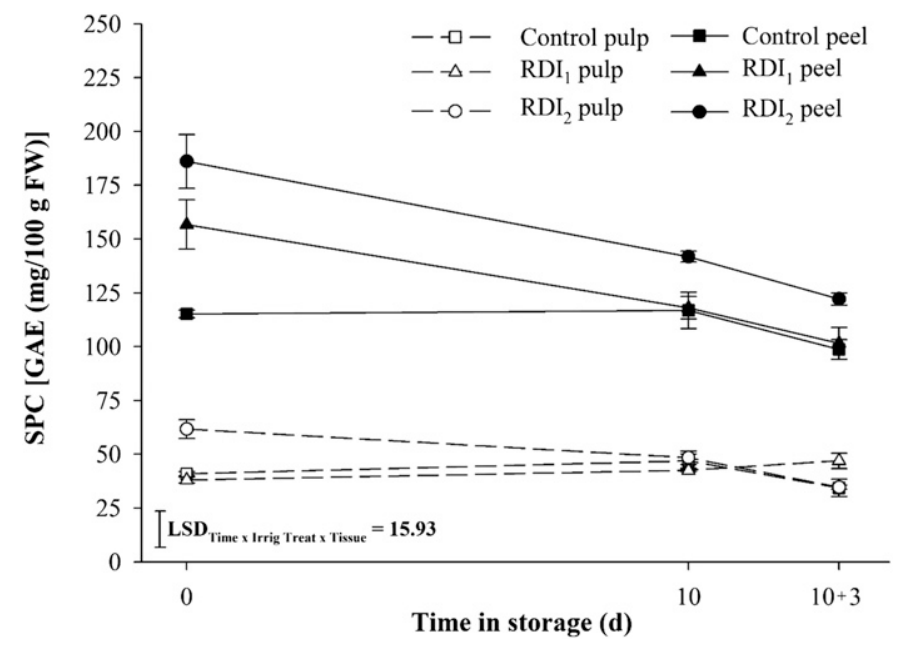

Fig. 1. Soluble phenolic content (SPC) expressed as milligrams of gallic acid equivalent (GAE) per $100 \mathrm{~g}$ fresh weight of 'VioWhite 5' nectarine fruit subjected to three different irrigation regimes \{control [irrigated at $110 \%$ of maximum crop evapotranspiration (ETc) during the whole season], $\mathrm{RDI}_{1}$ (irrigated at $110 \%$ ETc during critical periods of growth and at $85 \%$ of control during the rest of the growing season), $\mathrm{RDI}_{2}$ (irrigated at $110 \% \mathrm{ETc}$ during critical periods of growth and at $80 \%$ and $60 \%$ control during the second fruit growth stage in March and late postharvest, respectively) $\}$ and stored up to $10 \mathrm{~d}$ at $0{ }^{\circ} \mathrm{C}$ plus $3 \mathrm{~d}$ more at $15^{\circ} \mathrm{C}$. Data represent means of three replicates $( \pm \mathrm{SE})$; least significant difference $(5 \%)_{\text {time }} \times$ irrigation treatment $\times$ tissue $=15.93$.

compound biosynthesis pathways. The enzymes chosen in this study are some of the key enzymes in these pathways. CAT is the main enzyme that activates with high concentrations of ROS as $\mathrm{H}_{2} \mathrm{O}_{2}$. PAL is the primary enzyme in phenolic compound biosynthesis while PPO is responsible for their degradation. Besides, we have chosen APX, involved in vitamin $\mathrm{C}$ processes also affected by $\mathrm{RDI}$.

The objectives of this study were to elucidate the long-term effect of RDI treatments on extra-early nectarines over 3 years and their relation with selected secondary metabolites and related enzymes. Data obtained during the 3rd year are presented, showing the influence of long-term RDI on extraearly nectarine crops.

\section{Material and Methods}

EXPERIMENTAL SITE AND IRRIgation REgIMES. The field experiment was conducted from 2010 to 2013 in a commercial farm located in Murcia, Spain (lat. $38^{\circ} 8^{\prime} \mathrm{N}$, long. $1^{\circ} 13^{\prime} \mathrm{W}$ ). The 
Table 2. Changes in main individual phenolics and anthocyanin compounds of 'VioWhite 5' nectarine fruit subjected to three different irrigation regimes $(n=3)$.

\begin{tabular}{|c|c|c|c|c|c|c|c|c|}
\hline \multirow{2}{*}{$\begin{array}{l}\text { Time in } \\
\text { storage (d) }\end{array}$} & \multirow[b]{2}{*}{ Tissue } & \multirow{2}{*}{$\begin{array}{l}\text { Irrigation } \\
\text { regime }^{z}\end{array}$} & \multicolumn{6}{|c|}{ Individual phenolic and anthocyanin compounds $[\text { mean } \pm \mathrm{SE}(\mathrm{mg} / 100 \mathrm{~g} \text { fresh weight })]^{\mathrm{y}}$} \\
\hline & & & 1 & 2 & 3 & 4 & 5 & 6 \\
\hline \multirow[t]{6}{*}{ Initial } & Peel & Control & $99.21 \pm 0.48$ & $24.69 \pm 0.17$ & $24.80 \pm 0.31$ & $19.46 \pm 0.03$ & $29.43 \pm 0.33$ & $2.10 \pm 0.10$ \\
\hline & & $\mathrm{RDI}_{1}$ & $107.46 \pm 0.03$ & $26.49 \pm 0.02$ & $26.69 \pm 0.30$ & $24.72 \pm 0.30$ & $31.86 \pm 0.00$ & $1.85 \pm 0.02$ \\
\hline & & $\mathrm{RDI}_{2}$ & $120.38 \pm 0.09$ & $30.47 \pm 0.01$ & $33.40 \pm 0.40$ & $28.91 \pm 0.02$ & $33.33 \pm 0.17$ & $2.02 \pm 0.09$ \\
\hline & Pulp & Control & $7.88 \pm 0.00$ & $15.91 \pm 0.02$ & $4.61 \pm 0.31$ & $9.84 \pm 0.02$ & $\mathrm{nd}^{\mathrm{x}}$ & nd \\
\hline & & $\mathrm{RDI}_{1}$ & $8.21 \pm 0.03$ & $17.40 \pm 0.06$ & $4.87 \pm 0.30$ & $10.42 \pm 0.03$ & nd & nd \\
\hline & & $\mathrm{RDI}_{2}$ & $8.95 \pm 0.04$ & $17.96 \pm 0.02$ & $6.64 \pm 0.40$ & $11.22 \pm 0.03$ & nd & nd \\
\hline \multirow[t]{6}{*}{$10 \mathrm{~d}$ at $0{ }^{\circ} \mathrm{C}$} & Peel & Control & $100.41 \pm 0.15$ & $22.62 \pm 0.04$ & $10.98 \pm 0.62$ & $13.54 \pm 0.25$ & $23.62 \pm 0.08$ & $2.32 \pm 0.10$ \\
\hline & & $\mathrm{RDI}_{1}$ & $84.29 \pm 0.51$ & $18.32 \pm 0.10$ & $17.97 \pm 0.98$ & $15.87 \pm 0.01$ & $31.78 \pm 0.15$ & $2.43 \pm 0.11$ \\
\hline & & $\mathrm{RDI}_{2}$ & $85.74 \pm 0.09$ & $25.95 \pm 0.01$ & $20.84 \pm 1.35$ & $20.45 \pm 0.05$ & $28.31 \pm 0.29$ & $1.12 \pm 0.01$ \\
\hline & Pulp & Control & $4.63 \pm 0.00$ & $11.37 \pm 0.02$ & $3.34 \pm 0.24$ & $3.00 \pm 0.02$ & nd & nd \\
\hline & & $\mathrm{RDI}_{1}$ & $3.69 \pm 0.09$ & $12.45 \pm 0.17$ & $3.94 \pm 0.04$ & $3.95 \pm 0.05$ & nd & nd \\
\hline & & $\mathrm{RDI}_{2}$ & $3.31 \pm 0.00$ & $12.48 \pm 0.01$ & $4.29 \pm 0.01$ & $4.31 \pm 0.05$ & nd & nd \\
\hline \multirow{6}{*}{$\begin{array}{l}10 \mathrm{~d} \text { at } 0{ }^{\circ} \mathrm{C}+3 \mathrm{~d} \\
\text { at } 15^{\circ} \mathrm{C}\end{array}$} & Peel & Control & $39.31 \pm 0.01$ & $25.34 \pm 0.06$ & $11.88 \pm 0.76$ & $13.06 \pm 0.06$ & $15.19 \pm 0.52$ & $2.00 \pm 0.08$ \\
\hline & & $\mathrm{RDI}_{1}$ & $53.14 \pm 0.67$ & $18.37 \pm 0.02$ & $15.89 \pm 0.51$ & $15.90 \pm 0.01$ & $19.80 \pm 0.24$ & $1.11 \pm 0.00$ \\
\hline & & $\mathrm{RDI}_{2}$ & $59.02 \pm 0.84$ & $26.43 \pm 0.10$ & $19.01 \pm 0.40$ & $20.09 \pm 0.09$ & $22.11 \pm 0.31$ & $1.39 \pm 0.01$ \\
\hline & Pulp & Control & $2.27 \pm 0.09$ & $11.61 \pm 0.12$ & $1.43 \pm 0.76$ & $1.59 \pm 0.01$ & $\mathrm{nd}^{\mathrm{y}}$ & nd \\
\hline & & $\mathrm{RDI}_{1}$ & $4.25 \pm 0.01$ & $10.30 \pm 0.08$ & $1.58 \pm 0.51$ & $3.31 \pm 0.50$ & nd & nd \\
\hline & & $\mathrm{RDI}_{2}$ & $5.41 \pm 0.03$ & $13.79 \pm 0.03$ & $2.51 \pm 0.40$ & $3.65 \pm 0.01$ & nd & nd \\
\hline Irrigation treatment (A) & & & $(1.23)^{\mathrm{w} *}$ & $(0.19)^{*}$ & $(2.78)^{*}$ & $(0.25)^{*}$ & $(0.53)^{*}$ & $(0.05)^{*}$ \\
\hline Time (B) & & & $(1.23)^{*}$ & $(0.19)^{*}$ & $(2.78) *$ & $(0.25)^{*}$ & $(0.53)^{*}$ & $(0.05)^{*}$ \\
\hline Tissue (C) & & & $(1.00)^{*}$ & $(0.16)^{*}$ & $(2.27)^{*}$ & $(0.20)^{*}$ & $(0.43)^{*}$ & $(0.04)^{*}$ \\
\hline $\mathrm{A} \times \mathrm{B}$ & & & $(2.13)^{*}$ & $(0.33)^{*}$ & $\mathrm{NS}^{\mathrm{v}}$ & $(0.43)^{*}$ & $(0.92)^{*}$ & $(0.08)^{*}$ \\
\hline $\mathrm{A} \times \mathrm{C}$ & & & $(1.74)^{*}$ & $(0.27)^{*}$ & NS & $(0.35)^{*}$ & $(0.75)^{*}$ & $(0.07)^{*}$ \\
\hline $\mathrm{B} \times \mathrm{C}$ & & & $(1.74)^{*}$ & $(0.27)^{*}$ & $(3.93)^{*}$ & $(0.35)^{*}$ & $(0.75)^{*}$ & $(0.07)^{*}$ \\
\hline $\mathrm{A} \times \mathrm{B} \times \mathrm{C}$ & & & $(3.01)^{*}$ & $(0.47)^{*}$ & NS & $(0.60)^{*}$ & $(1.30)^{*}$ & $(0.12)^{*}$ \\
\hline
\end{tabular}

${ }^{\mathrm{z}}$ Control $=$ irrigated at $110 \%$ of maximum crop evapotranspiration (ETc) during the whole season, $\mathrm{RDI}_{1}=$ irrigated at $110 \%$ ETc during critical periods of growth and at $85 \%$ of control during the rest of the growing season, $\mathrm{RDI}_{2}=$ irrigated at $110 \%$ ETc during critical periods of growth and at $80 \%$ and $60 \%$ control during the second fruit growth stage in March and late postharvest, respectively.

${ }^{\mathrm{y}} 1=$ chlorogenic acid; $2=$ neochlorogenic acid; $3=$ catechin; $4=$ caffeic acid; $5=$ cyanidin 3 -glucoside; $6=$ cyanidin 3 -rutinoside.

${ }^{x}$ nd $=$ non detected.

${ }^{\mathrm{w}}$ Least significant difference values are in parentheses; ${ }^{*} P<0.05$.

${ }^{\mathrm{N}} \mathrm{N}=$ not significant.

experimental plot had an area of 2 ha and consisted of 11 -yearold 'VioWhite 5' nectarine trees (extra-early), grafted onto plum (Prunus domestica L. cv. Puebla de Soto 101) rootstock at a spacing of $6 \times 3.5 \mathrm{~m}$. This cultivar was chosen because of its high commercial value due to its early picking date, which commands a high market price, and its suitable size for European sales. Its blooming date is the last week of January as it is harvested the last week of April. The soil was a clay loam (41.6\% sand, $25.0 \%$ silt, and $33.4 \%$ clay) with an average depth of $1.55 \mathrm{~m}$, field capacity of $31 \%$, low-available potassium, low phosphorus, and low organic matter content $(2.0 \%)$ in the main root zone of the soil at the beginning of the study. The electrical conductivity (EC) of the irrigation water varied between 1.5 and $2.5 \mathrm{dS} \cdot \mathrm{m}^{-1}$, depending on the source used (irrigation canal, well, or a mix of both). Normal cultivation practices (e.g., weed control, fertilization, pruning, fruit thinning, and banding) were carried out by the technical department of the commercial orchard. The drip irrigation system had two lines per tree row and 9.33 pressure-compensated emitters $\left(1.6 \mathrm{~L} \cdot \mathrm{h}^{-1}\right)$ per tree, placed every $75 \mathrm{~cm}$. Irrigation was scheduled weekly and applied with a frequency that varied from one to two times per day in spring-summer to one to seven times per week for the rest of the year. The start time of any irrigation was the same for all the treatments, and was done at night.
During the experiment, three irrigation treatments were applied 1) control, irrigated at $110 \%$ of ETc during the whole season to avoid limiting soil water conditions, determined from the ETc reference guidelines (Penman-Monteith; Allen et al., 1998); 2) $\mathrm{RDI}_{1}$, irrigated at $110 \%$ ETc during the critical periods (third fruit growth stage and the beginning of postharvest) and at $85 \%$ of control during the rest of the growing season; and 3) $\mathrm{RDI}_{2}$, irrigated at $110 \%$ ETc during the mentioned critical periods and at $80 \%$ and $60 \%$ control during the second fruit growth stage in March and late postharvest (from July until November), respectively. The experimental design consisted of three replicates per treatment, randomly distributed within the orchard. Each replicate had three adjacent tree rows and 15 trees per row. Measurements were taken from trees in the central row, the other trees serving as borders (Falagán et al., 2015).

Tree water status. Midday (1200 HR) stem water potential $\left(\Psi_{\text {stem }}\right)$ was measured with a pressure chamber (model 3000 Plant Water Status Console; Soil Moisture Equipment Corp., Santa Barbara, CA) according to the procedure described by Hsiao (1990), every 7-10 d in six adult leaves per treatment that were enclosed in foil-covered plastic and aluminum envelopes at least $2 \mathrm{~h}$ before the measurement. 


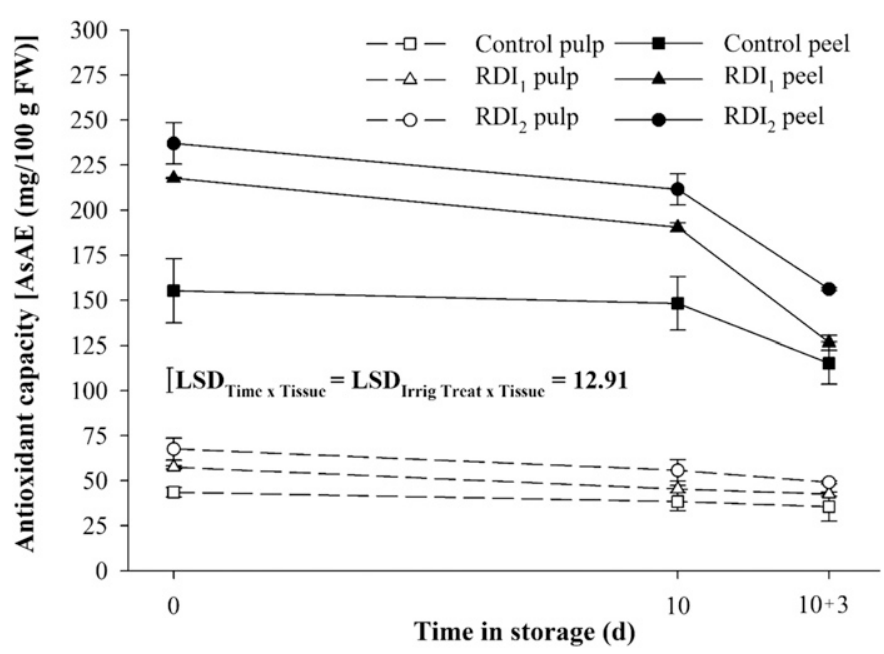

Fig. 2. Total antioxidant capacity expressed as milligrams of ascorbic acid equivalent (AsAE) per $100 \mathrm{~g}$ fresh weight of 'VioWhite 5' nectarine fruit subjected to three different irrigation regimes \{control [irrigated at $110 \%$ of maximum crop evapotranspiration (ETc) during the whole season], $\mathrm{RDI}_{1}$ (irrigated at $110 \%$ ETc during critical periods of growth and at $85 \%$ of control during the rest of the growing season), $\mathrm{RDI}_{2}$ (irrigated at $110 \%$ ETc during critical periods of growth and at $80 \%$ and $60 \%$ control during the second fruit growth stage in March and late postharvest, respectively) $\}$ and stored up to $10 \mathrm{~d}$ at $0{ }^{\circ} \mathrm{C}$ plus $3 \mathrm{~d}$ more at $15^{\circ} \mathrm{C}$. Data represent means of three replicates $(\mathrm{n}=3 \pm \mathrm{SE})$. Least significant difference $(\mathrm{LSD})(5 \%)_{\text {time }} \times$ tissue $=$ $\operatorname{LSD}(5 \%)_{\text {treatment }} \times$ tissue $=12.91$.

The water stress integral was calculated annually from the midday $S_{\Psi \text { stem }}$ values (megapascals per day), as in Myers (1988), to calculate the intensity of the water stress applied.

$$
S_{\Psi \text { stem }}=\sum_{i=0}^{i=t}\left(\overline{\Psi_{\text {stem }_{i, i+1}-} \Psi_{\text {stemcontrol }_{i, i+1}}}\right)^{n}
$$

Postharvest Storage Conditions. For three consecutive years, three nectarine harvests were studied. Data obtained during the 3rd year are presented. This 3rd-year data are consistent and accurate with the one registered in the previous two seasons. The 3 years followed the same trend and data were in the same range, providing repeatability, precision, and reliability to the study.

Nectarine fruit were collected at the beginning of ripening ( $\approx 26$ Apr.) according to commercial criteria, which is based on the maturity index (Table 1) with an average caliber of (mean \pm SE) $61.56 \pm 0.49 \mathrm{~mm}$ and an average weight of $115.6 \pm 1.17 \mathrm{~g}$. At harvest, around $60 \mathrm{~kg}$ per irrigation treatment were sampled and immediately transported $45 \mathrm{~km}$ by car under refrigerated conditions to the Pilot Plant of the Postharvest and Refrigeration Group in the Technical University of Cartagena. Fruit were selected by eliminating those with external defects or bruises. Sound nectarine fruit were located into boxes and stored at $0 \pm$ $0.5{ }^{\circ} \mathrm{C}$ and $90 \%$ to $95 \% \mathrm{RH}$ in air for $10 \mathrm{~d}$. Then, a simulated retail sale period of $3 \mathrm{~d}$ at $15^{\circ} \mathrm{C}$ and $70 \%$ to $75 \% \mathrm{RH}$ in air was carried out. For each sampling day $(0,10$, and $13 \mathrm{~d})$, three repetitions ( 12 fruit/each) per treatment were used. For the analysis of secondary metabolites and enzymes, peel (exocarp) and pulp (mesocarp) were separated, cut into small pieces, frozen in liquid $\mathrm{N}_{2}$, ground to a fine powder with an analytical mill (A 11 basic; IKA, Berlin, Germany), and stored at $-80^{\circ} \mathrm{C}$ until analyzed.

Soluble Phenolic CONTENT. Frozen, ground samples of pulp $(0.850 \mathrm{~g})$ and peel $(0.60 \mathrm{~g})$ were placed in glass bottles and $3 \mathrm{~mL}$ of methanol:water $(7: 3, \mathrm{v} / \mathrm{v}$; Panreac, Barcelona, Spain) was added. The extraction was carried out for $1 \mathrm{~h}$ in an orbital shaker (SSL1; Stuart, Stone, UK) at $200 g_{n}$ in darkness inside a polystyrene box filled with ice. Then, $1.5 \mathrm{~mL}$ of extracts were transferred to three $1.5-\mathrm{mL}$ microcentrifuge tubes and centrifuged at $15,000 \mathrm{~g}_{\mathrm{n}}$ for $10 \mathrm{~min}$ at $4{ }^{\circ} \mathrm{C}$. The amount of soluble phenolic content (SPC) in the supernatant obtained was determined according to Swain and Hillis (1959) with slight modifications as described in Falagán et al. (2014). SPC was expressed as gallic acid equivalents (GAE) per $100 \mathrm{~g}$ fresh weight $(\mathrm{FW})$. All measurements were analyzed by three technical replicates.

EXTRACTION AND QUANTIFICATION OF INDIVIDUAL PHENOLIC AND ANTHOCYANIN COMPOUNDS. Five grams of frozen peel and pulp samples were homogenized with $10 \mathrm{~mL}$ of a water: methanol solution $(2: 8, \mathrm{v} / \mathrm{v})$ containing $2 \mathrm{~mm} \mathrm{NaF}$ (Panreac), according to Tomás-Barberán et al. (2001). Homogenates were centrifuged $\left(15,000 \mathrm{~g}_{\mathrm{n}}, 15 \mathrm{~min}, 4{ }^{\circ} \mathrm{C}\right)$ and supernatants were filtered through a $0.45-\mu \mathrm{m}$ filter. Right after, $20 \mu \mathrm{L}$ of the extracts were analyzed using a UPLC LC-30AD system (Shimadzu, Tokyo, Japan) equipped with a degasser (DGU20A; Shimadzu), an autosampler (SIL-30AC; Shimadzu), a column oven (CTO-10AS; Shimadzu), a communications module (CMB-20A; Shimadzu), and a diode array detector (SPDM-20A; Shimadzu). The column used was a Gemini NX $(250 \mathrm{~mm} \times 4.6 \mathrm{~mm}, 5 \mu \mathrm{m}) \mathrm{C} 18$ column (Phenomenex, Torrance, CA). The mobile phases consisted of $95 \%$ water + $5 \%$ methanol; $88 \%$ water $+12 \%$ methanol; $20 \%$ water $+80 \%$ methanol; and 100\% methanol, following the gradient detailed in Tomás-Barberán et al. (2001). For quantification of individual phenolics and anthocyanins, external standards were used according to Artés-Hernández et al. (2006).

Antioxidant CAPACITy. The extraction procedures used were as described for SPC. The total antioxidant capacity was determined as according to Benzie and Strain (1996), with small changes as reported in Falagán et al. (2014). Results were expressed as AsA equivalent (AsAE) per $100 \mathrm{~g} \mathrm{FW}$ All measurements were analyzed by three technical replicates.

Vitamin C Content. For monitoring vitamin C content, the procedure used was as reported by Silveira et al. (2013). Five grams of ground, frozen samples were placed in a conical tube protected against light, and $10 \mathrm{~mL}$ citric acid buffer $(0.1 \mathrm{M}$ citric acid; Sigma-Aldrich, St. Louis, MO), 0.05\% ethylenediaminetetraacetic acid (EDTA; Sigma-Aldrich), $4 \mathrm{mmol} \cdot \mathrm{L}^{-1} \mathrm{NaF}$ (Panreac), and $50 \mathrm{~mL} \cdot \mathrm{L}^{-1}$ methanol in nanopure water were added. They were homogenized in a high-speed blender (Ultraturrax T-18 basic; IKA, Guangzhou, China) for $30 \mathrm{~s}$. The homogenate was filtered through cheesecloth and after adjusting the $\mathrm{pH}$ to $2.3-2.4$ using $\mathrm{HCl}$ (6 N; Panreac), the sample was passed through an activated Sep-Pak C18 cartridge (Waters, Mildford, MA). $750 \mu \mathrm{L}$ of the extraction was kept in a $1.5-\mathrm{mL}$ amber vial. Then, $250 \mu \mathrm{L}$ of 1,2-phenylenediamine dihydrochloride solution $(35 \mathrm{mg} / 100 \mathrm{~mL})$ was added to the vial, and after $37 \mathrm{~min}$ in darkness, samples were analyzed by high-performance liquid chromatography (Series 1100; Agilent Technologies, Waldbronn, Germany). Total vitamin $\mathrm{C}$ was expressed as the sum of both AsA and dehydroascorbic acid (DHA) per $100 \mathrm{~g} \mathrm{FW}$.

\section{Enzymatic Activity}

Catalase (EC 1.11.1.6). Three grams of fresh tissue were extracted with $6 \mathrm{~mL}$ of $50 \mathrm{~mm}$ potassium phosphate (Panreac) buffer (pH 7.8) containing $0.1 \mathrm{~mm}$ of EDTA, $5 \mathrm{~mm}$ L-cysteine, and $0.2 \%$ of Triton X-100 (Panreac). To each sample, $0.12 \mathrm{~g}$ 


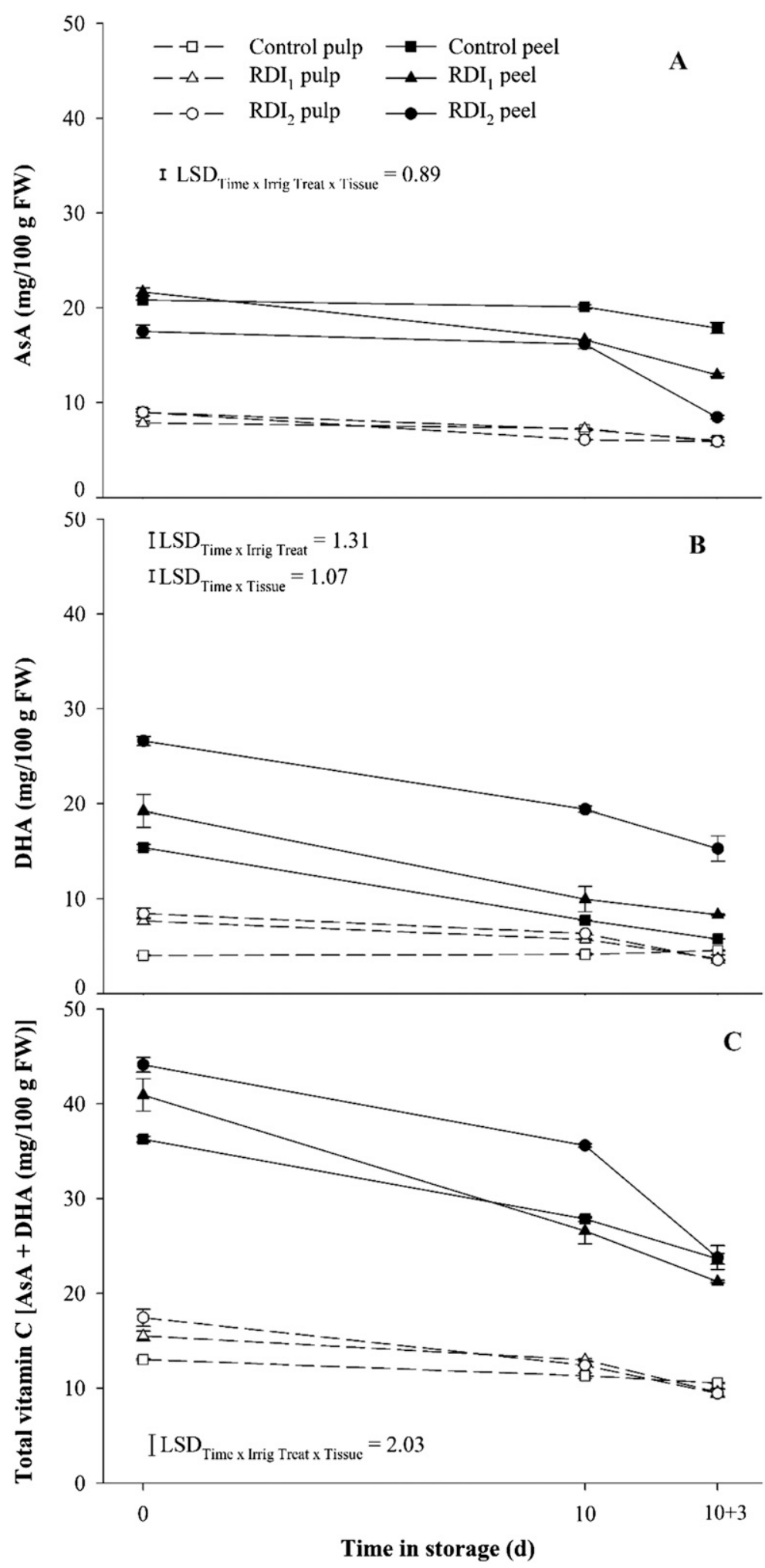

Fig. 3. Vitamin C of 'Viowhite 5' nectarine fruit subjected to three different irrigation regimes \{control [irrigated at $110 \%$ of maximum crop evapotranspiration (ETc) during the whole season], $\mathrm{RDI}_{1}$ (irrigated at $110 \%$ ETc during critical periods of growth and at $85 \%$ of control during the rest of the growing season), $\mathrm{RDI}_{2}$ (irrigated at $110 \%$ ETc during critical periods of growth and at $80 \%$ and $60 \%$ control during the second fruit growth stage in March and late postharvest, respectively) $\}$ and stored up to $10 \mathrm{~d}$ at $0{ }^{\circ} \mathrm{C}$ plus $3 \mathrm{~d}$ more at $15^{\circ} \mathrm{C}$. Total vitamin $\mathrm{C}$ content $(\mathrm{C})$ is expressed as the sum of both ascorbic acid [AsA (A)] and dehydroascorbic acid [DHA (B)] contents. Data represent means of three replicates $( \pm \mathrm{SE})$. For AsA, least significant difference (LSD) $(5 \%)_{\text {time }} \times$ irrigation treatment $\times$ tissue $=0.89$. In the case of DHA, LSD $(5 \%)_{\text {time }} \times$ irrigation treatment $=1.31 ; \mathrm{LSD}(5 \%)_{\text {time }} \times$ tissue $=$ LSD $(5 \%)_{\text {irrigation treatment } \times \text { tissue } 1.07 \text {. Finally, for total vitamin C, LSD }(5 \%)_{\text {time }} \times \text { irrigation treatment } \times \text { tissue }}=2.03$. of polyvinylpolypyrrolidone (PVPP; Panreac) and $60 \mu \mathrm{L}$ of phenylmethanesulfonyl fluoride (Sigma-Aldrich) were added. Then, the mixture was blended with a high-speed blender (Ultraturrax T-18 basic). The homogenate was centrifuged at $23,500 g_{n}$ for $5 \mathrm{~min}$ at $4{ }^{\circ} \mathrm{C}$. The resulting supernatants were purified using desalting columns (PD10; GE Healthcare Bio-Sciences, Pittsburgh, PA). Every step was carried out in dark and cold conditions. CAT activity was determined by spectrophotometric measurements at $25^{\circ} \mathrm{C}$ according to Wang et al. (2005) with modifications. The reaction mixture consisted of $290 \mu \mathrm{L}$ potassium phosphate buffer with $10.6 \mathrm{~mm}$ $\mathrm{H}_{2} \mathrm{O}_{2}$ (50 mm, pH 7; Panreac) and $10 \mu \mathrm{L}$ of the enzyme placed on a 96-well flat-bottom polystyrene plate (Greiner Bio-one, Frickenhausen, Germany) and read at $290 \mathrm{~nm}$. The specific activity was expressed as units per milligram protein, where $1 \mathrm{U}$ of CAT converts $1 \mu \mathrm{mol} \cdot \mathrm{min}^{-1}$ $\mathrm{H}_{2} \mathrm{O}_{2}\left(\varepsilon=39.58 \mathrm{~mm}^{-1} \cdot \mathrm{cm}^{-1}\right)$.

Polyphenol oxidase (EC 1.14.18.1). PPO was extracted with $0.1 \mathrm{M}$ sodium phosphate buffer $(\mathrm{pH}$ 6.5; Panreac) containing 0.4 $\mathrm{M}$ catechol (Sigma-Aldrich) and $50 \mathrm{~g} \cdot \mathrm{L}^{-1}$ of PVPP. Samples were homogenized with a polytron. Then, homogenates were filtered and centrifuged $\left(19,500 g_{\mathrm{n}} \times 30 \mathrm{~min} \times\right.$ $4{ }^{\circ} \mathrm{C}$ ). Supernatants were analyzed as described in Cabezas-Serrano et al. (2009) with slight modifications. Every step was carried out in dark and cold conditions. A mixture of $75 \mu \mathrm{L}$ of extract and $225 \mu \mathrm{L}$ of $0.1 \mathrm{~m}$ sodium phosphate buffer $(\mathrm{pH}$ 6.5 ) with $0.4 \mathrm{~m}$ catechol were analyzed by spectrophotometric methods at $400 \mathrm{~nm}$ and $25{ }^{\circ} \mathrm{C}$ for a period of $3 \mathrm{~min}$. One unit of PPO activity was defined as the amount of enzyme that caused an increase of 1 absorbance unit in $1 \mathrm{~min}$ at $400 \mathrm{~nm}$ $\left(\varepsilon=3450 \mathrm{M}^{-1} \cdot \mathrm{cm}^{-1}\right.$ ) according to Falguera et al. (2012).

Phenylalanine ammonia-lyase (EC 4.3.1.5). PAL activity was determined with $50 \mathrm{~mm}$ borate buffer (Panreac) at $\mathrm{pH} 8.5$, according to Ke and Saltveit (1986). Four grams were homogenized in $16 \mathrm{~mL}$ of buffer containing $0.4 \mathrm{~g}$ of PVPP and $16 \mu \mathrm{L} \cdot \mathrm{L}^{-1}$ of mercaptoethanol 


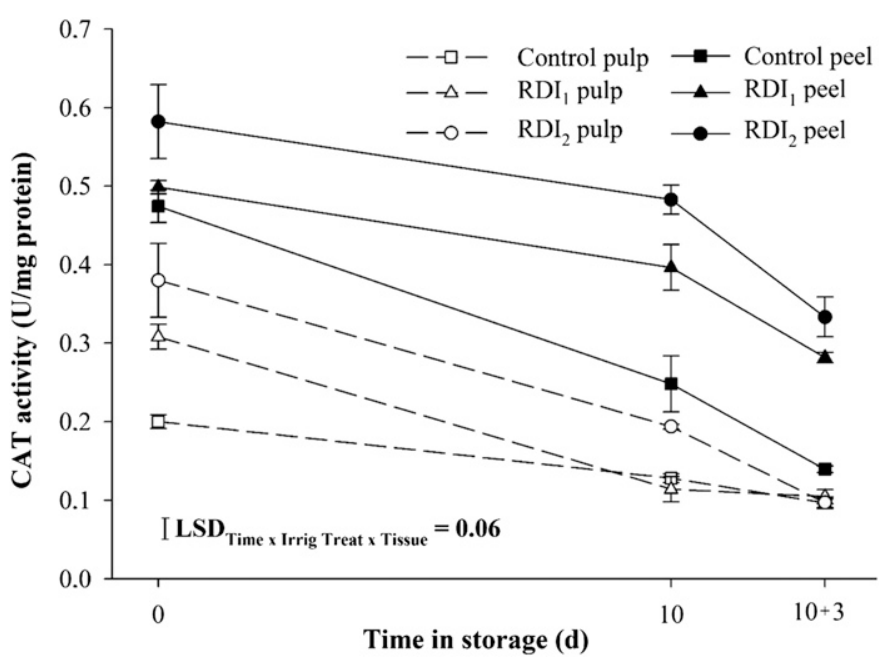

Fig. 4. Catalase activity expressed as units per milligram protein of 'VioWhite 5 ' nectarine fruit subjected to three different irrigation regimes \{control [irrigated at $110 \%$ of maximum crop evapotranspiration (ETc) during the whole season], $\mathrm{RDI}_{1}$ (irrigated at $110 \%$ ETc during critical periods of growth and at $85 \%$ of control during the rest of the growing season), $\mathrm{RDI}_{2}$ (irrigated at $110 \%$ ETc during critical periods of growth and at $80 \%$ and $60 \%$ control during the second fruit growth stage in March and late postharvest, respectively) $\}$ and stored up to $10 \mathrm{~d}$ at $0{ }^{\circ} \mathrm{C}$ plus $3 \mathrm{~d}$ more at $15{ }^{\circ} \mathrm{C}$. Data represent means of three replicates $( \pm \mathrm{SE})$. Least significant difference $(5 \%)_{\text {time }} \times$ irrigation treatment $\times$ tissue $=0.06$.

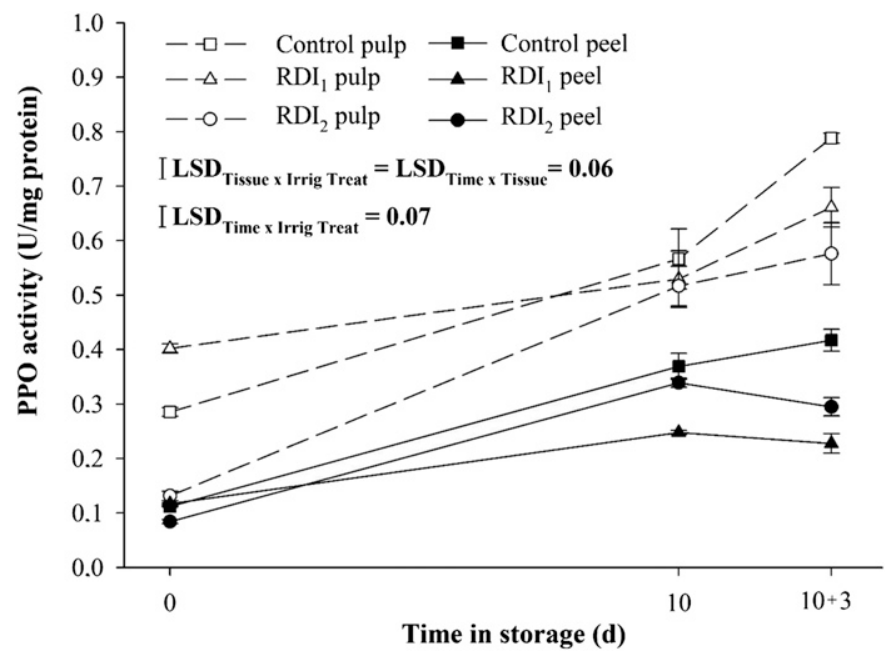

Fig. 5. Polyphenol oxidase activity expressed as units per milligram protein of 'VioWhite 5' nectarine fruit subjected to three different irrigation regimes \{control [irrigated at $110 \%$ of maximum crop evapotranspiration (ETc) during the whole season], $\mathrm{RDI}_{1}$ (irrigated at $110 \%$ ETc during critical periods of growth and at $85 \%$ of control during the rest of the growing season), $\mathrm{RDI}_{2}$ (irrigated at $110 \%$ ETc during critical periods of growth and at $80 \%$ and $60 \%$ control during the second fruit growth stage in March and late postharvest, respectively) $\}$ and stored up to $10 \mathrm{~d}$ at $0{ }^{\circ} \mathrm{C}$ plus $3 \mathrm{~d}$ more at $15{ }^{\circ} \mathrm{C}$. Data represent means of three replicates $( \pm \mathrm{SE})$. Least significant

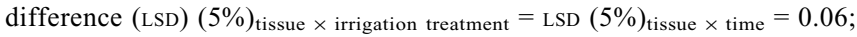
LSD $(5 \%)_{\text {time }} \times$ irrigation treatment $=0.07$.

(Sigma-Aldrich) at $4{ }^{\circ} \mathrm{C}$. The homogenate was filtered and centrifuged at $32,000 \times g_{\mathrm{n}}$ for $15 \mathrm{~min}$ at $4{ }^{\circ} \mathrm{C}$. Every step was carried out in dark and cold conditions. The substrate used for the reaction was phenylalanine (100 mm; Sigma-Aldrich). PAL enzyme activity was determined spectrophotometrically as the amount of enzyme that produced $1 \mu \mathrm{mol} \cdot \mathrm{min}^{-1}$ cinnamic acid $\left(\varepsilon=0.977 \mathrm{~mm}^{-1} \cdot \mathrm{cm}^{-1}\right)$ at $290 \mathrm{~nm}$ at $40{ }^{\circ} \mathrm{C}$.

AsCORBATE PEROXIDASE (EC 1.11.1.11). The extraction of APX was carried out as described by Nakano and Asada (1981). One gram of sample was homogenized with $4 \mathrm{~mL}$ of $50 \mathrm{~mm}$ sodium phosphate buffer ( $\mathrm{pH} 7$ ), containing $0.1 \mathrm{~mm}$ EDTA, $1 \mathrm{~mm}$ AsA, and 1\% PVPP with a high-speed blender (Ultraturrax $\mathrm{T}-18$ basic). Then, the homogenate was centrifuged at $10,000 \times g_{\mathrm{n}}$ for $20 \mathrm{~min}$ at $4^{\circ} \mathrm{C}$. The supernatants were purified using PD10 desalting columns. Every step was carried out in darkness and cold conditions. Measurements were carried out at $290 \mathrm{~nm}$. The specific activity was expressed as units per milligram protein, where $1 \mathrm{U}$ of APX activity was defined as the amount of enzyme that caused an oxidation of $1 \mu \mathrm{mol} \cdot \mathrm{min}^{-1}$ of AsA at $30{ }^{\circ} \mathrm{C}\left(\varepsilon=2.8 \mathrm{~mm}^{-1} \cdot \mathrm{cm}^{-1}\right)$.

Protein Determination. The content of protein was determined according to the method described in Bradford (1976), using bovine serum albumin (Sigma-Aldrich) as the standard protein.

Statistical analysis. The interaction among irrigation treatment and storage time was studied by conducting a bifactorial analysis of variance using the Statgraphics Centurion software (version XV.II; StatPoint, Warrenton, VA) for each response at a significant level of $P \leq 0.05$. When differences were found, the mean value was analyzed by the least significant difference test, which is shown in the figures.

\section{Results}

WATER SUPPLY AND TREE WATER STATUS. The annual amount of irrigation water applied in each irrigation treatment was quantified. Control trees received more water as the experiment progressed due to the increase in water demand. The mean irrigation volumes applied during the 3-year trial were 6540 , 5760 , and $4490 \mathrm{~m}^{3} \cdot \mathrm{ha}^{-1}$ per year (for control, $\mathrm{RDI}_{1}$, and $\mathrm{RDI}_{2}$, respectively). The total seasonal reduction of water usage averaged $12 \%$ and $32 \%$ in $\mathrm{RDI}_{1}$ and $\mathrm{RDI}_{2}$, respectively, with respect to the control treatment. The $\mathrm{S} \Psi_{\text {stem }}$ values were substantially higher in $\mathrm{RDI}_{2}$ due to the greater reduction in the water applied, with $\mathrm{S} \Psi_{\text {stem }}$ averaging -1.2 and $-0.2 \mathrm{MPa} \cdot \mathrm{d}^{-1}$ during the fruit growth stage in $\mathrm{RDI}_{2}$ and $\mathrm{RDI}_{1}$, respectively.

Soluble Phenolic content. The changes in SPC content according to the type of irrigation treatment and storage time are shown in Fig. 1. Peel extracts contained a higher SPC than pulp, and initially, peel from nectarine fruit under the $\mathrm{RDI}_{2}$ watering regime contained a higher SPC than the other irrigation treatments $(186.10 \pm 12.53 \mathrm{mg}$ GAE per $100 \mathrm{~g} \mathrm{FW}$ vs. $156.75 \pm 11.47$ and $115.17 \pm 1.77 \mathrm{mg} \mathrm{GAE} \mathrm{per} 100 \mathrm{~g} \mathrm{FW}$ for $\mathrm{RDI}_{1}$ and control, respectively). This difference was maintained through most of the experiment, followed by a decreasing trend. On the other hand, the SPC detected in pulp showed more stable values. At day $0, \mathrm{RDI}_{2}$ presented a higher content $(61.70 \pm$ 4.36 vs. $38.05 \pm 1.40$ and $40.91 \pm 0.94$ for $\mathrm{RDI}_{1}$ and control, respectively), but after cold storage no differences were found. At the end of the retail sale period, the initial values were best preserved in $\mathrm{RDI}_{1}$ nectarine fruit.

INDIVIDUAL PHENOLIC AND ANTHOCYANIN COMPOUNDS. The individual phenolic and anthocyanin compounds characterized in peel and pulp of nectarine fruit are shown in Table 2. As reported for the previous analysis, the greatest amount of phenolic and anthocyanin compounds was found in the peel. The most abundant polyphenol in the peel was chlorogenic acid, followed by 


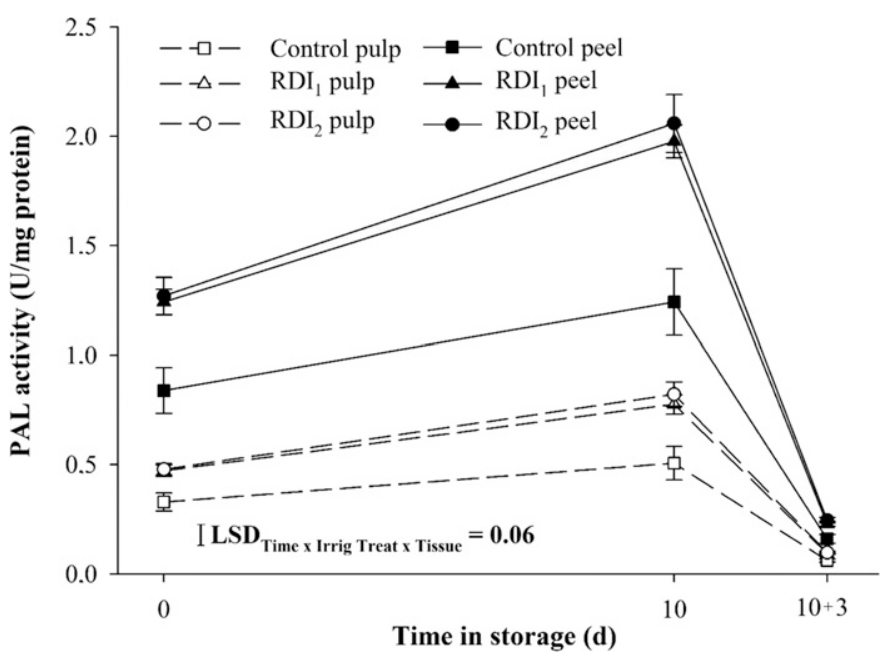

Fig. 6. Phenylalanine ammonia-lyase activity expressed as units per milligram protein of 'VioWhite 5' nectarine fruit subjected to three different irrigation regimes \{control [irrigated at $110 \%$ of maximum crop evapotranspiration (ETc) during the whole season], $\mathrm{RDI}_{1}$ (irrigated at $110 \%$ ETc during critical periods of growth and at $85 \%$ of control during the rest of the growing season), $\mathrm{RDI}_{2}$ (irrigated at $110 \% \mathrm{ETc}$ during critical periods of growth and at $80 \%$ and $60 \%$ control during the second fruit growth stage in March and late postharvest, respectively) $\}$ and stored up to $10 \mathrm{~d}$ at $0{ }^{\circ} \mathrm{C}$ plus $3 \mathrm{~d}$ more at $15{ }^{\circ} \mathrm{C}$. Data represent means of three replicates $( \pm \mathrm{SE})$. Least significant difference $(5 \%)_{\text {time }} \times$ irrigation treatment $\times$ tissue $=0.06$.

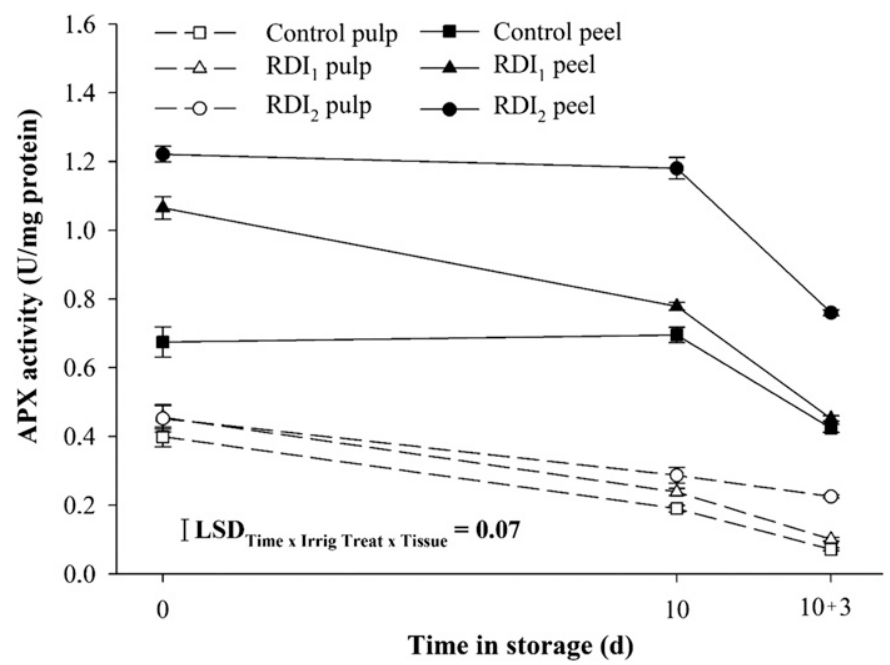

Fig. 7. Ascorbate peroxidase activity expressed as units per milligram protein of 'VioWhite 5' nectarine fruit subjected to three different irrigation regimes \{control [irrigated at $110 \%$ of maximum crop evapotranspiration (ETc) during the whole season], $\mathrm{RDI}_{1}$ (irrigated at $110 \%$ ETc during critical periods of growth and at $85 \%$ of control during the rest of the growing season), $\mathrm{RDI}_{2}$ (irrigated at $110 \%$ ETc during critical periods of growth and at $80 \%$ and $60 \%$ control during the second fruit growth stage in March and late postharvest, respectively) $\}$ and stored up to $10 \mathrm{~d}$ at $0{ }^{\circ} \mathrm{C}$ plus $3 \mathrm{~d}$ more at $15{ }^{\circ} \mathrm{C}$. Data represent means of three replicates $( \pm \mathrm{SE})$. Least significant difference $(5 \%)_{\text {time }} \times$ irrigation treatment $\times$ tissue $=0.07$.

neochlorogenic acid, catechin, and caffeic acid. However, in the pulp, neochlorogenic acid was the most abundant followed by caffeic acid. All of these individual phenolics were particularly high in fruit from $\mathrm{RDI}_{2}$ followed by $\mathrm{RDI}_{1}$. All the samples suffered a reduction after cold storage and retail sale period. Anthocyanins were not detected in the pulp, but two main anthocyanins were quantified in the peel:cyanidin 3-glucoside and cyanidin 3-rutinoside.
The content of cyanidin 3-glucoside was higher than cyanidin 3 -rutinoside in all the treatments. The concentration of these compounds followed a decreasing trend, with $\mathrm{RDI}_{2}$ being the treatment that showed the least amount of change in the concentration of these bioactive compounds at the end of the treatment.

Antioxidant CAPaCiTy. Antioxidant capacity was highly correlated with SPC content $(r=0.98)$, and a greater concentration of antioxidant compounds was again found in the peel rather than in flesh. $\mathrm{RDI}_{2}$ peel had the highest values $(236.99 \pm$ $11.38 \mathrm{mg}$ AsAE per $100 \mathrm{~g} \mathrm{FW}$ vs. $217.72 \pm 0.24$ and $155.17 \pm$ $17.79 \mathrm{mg}$ AsAE per $100 \mathrm{~g} \mathrm{FW}$ for $\mathrm{RDI}_{1}$ and control peels, respectively), but a decreasing trend was observed in all treatments (Fig. 2). As for the behavior observed for the SPC, the pulp showed a lesser decline than the peel and at the end of the experiment, no significant differences among treatments were noticed in the nectarine's pulp tissue.

Vitamin C Content. The change in vitamin $\mathrm{C}$ content is shown in Fig. 3. The study of this vitamin is divided into its two biologically active forms: AsA and DHA, with the sum of these two forms adding to total vitamin $\mathrm{C}$. In the case of AsA, control peel samples reached the highest content at the end of the retail sale period $(17.87 \pm 0.01 \mathrm{mg}$ AsA per $100 \mathrm{~g} \mathrm{FW}$ vs. $12.92 \pm 0.41$ and $8.46 \pm 0.67 \mathrm{mg}$ AsA per $100 \mathrm{~g} \mathrm{FW}$ for $\mathrm{RDI}_{1}$ and $\mathrm{RDI}_{2}$ peels, respectively). However, no differences were found among the pulp tissues of any treatment, with the range of values being below than of peel (Fig. 3A). This response was opposite to the DHA results. The peel from nectarine fruit under $\mathrm{RDI}_{2}$ had higher DHA content than the other two irrigation treatments during the whole study (Fig. 3B). Initially, $\mathrm{RDI}_{2}$ had the highest content of vitamin $\mathrm{C}$ (44.12 \pm $0.76 \mathrm{mg}$ AsA per $100 \mathrm{~g} \mathrm{FW}$ vs. $40.92 \pm 1.71$ and $36.26 \pm 0.76 \mathrm{mg}$ per AsA $100 \mathrm{~g} \mathrm{FW}$ for $\mathrm{RDI}_{1}$ and control peels, respectively). These values followed a decreasing trend with storage time, and at the end of the study no differences were observed. The same behavior was observed in pulp, but with overall lower levels (Fig. 3C).

ENZYMATIC ACTIVITY. Initially, peels from $\mathrm{RDI}_{2}$ nectarine fruit reached the maximum $\mathrm{CAT}$ activity registered in the experiment $(0.58 \pm 0.05 \mathrm{U} / \mathrm{mg}$ protein vs. $0.50 \pm 0.01$ and $0.47 \pm$ $0.02 \mathrm{U} / \mathrm{mg}$ protein for $\mathrm{RDI}_{1}$ and control peels, respectively). CAT activity gradually decreased with storage time. This loss of activity was more pronounced in control samples, and at the end of the retail sale period, peels from $\mathrm{RDI}_{2}$ nectarine fruit still showed more CAT activity (Fig. 4). During the whole experiment, the CAT activity in the pulp was lower than in the peel and in contrast, the PPO showed the opposite behavior. The main activity was detected in the pulp and followed by an increasing trend with storage time. Initially, $\mathrm{RDI}_{1}$ nectarine fruit presented the highest PPO activity (Fig. 5), but after $10 \mathrm{~d}$ of cold storage no differences were found in the pulp among the treatments. During the retail sale period, pulp of control nectarine fruit had an increase in PPO activity, rising over the other treatments. The peel followed a parallel behavior, but always under the pulp levels (Fig. 5). On initial evaluation, $\mathrm{RDI}_{1}$ and $\mathrm{RDI}_{2}$ peel showed the highest PAL activity followed by control peel (Fig. 6), but after cold storage, all treatments registered an increasing trend. This tendency changed during the retail sale period when PAL activity showed a gradual decrease. Pulp samples showed a similar behavior, but again, at lower levels. At the end of the experiment, results in all treatments were very close, but a higher activity in peel than in pulp was still found (Fig. 6). As for APX, the highest activity was found in the peel, and especially in the nectarine fruit under the $\mathrm{RDI}_{2}$ treatment $(1.22 \pm 0.02 \mathrm{U} / \mathrm{mg}$ protein vs. $1.06 \pm 0.03$ and $0.67 \pm 0.04 \mathrm{U} / \mathrm{mg}$ protein, for $\mathrm{RDI}_{1}$ 
Table 3. Correlation coefficients among individual polyphenols and anthocyanins and antioxidant capacity and soluble phenolic content (SPC). Influence of individual components on total contents of 'VioWhite 5' nectarine fruit subjected to three different irrigation regimes \{control [irrigated at $110 \%$ of maximum crop evapotranspiration (ETc) during the whole season], $\mathrm{RDI}_{1}$ (irrigated at $110 \%$ ETc during critical periods of growth and at $85 \%$ of control during the rest of the growing season), $\mathrm{RDI}_{2}$ (irrigated at $110 \% \mathrm{ETc}$ during critical periods of growth and at $80 \%$ and $60 \%$ control during the second fruit growth stage in March and late postharvest, respectively) $\}$.

\begin{tabular}{|c|c|c|c|c|c|c|c|c|}
\hline \multirow{2}{*}{$\begin{array}{l}\text { Phenolic and } \\
\text { anthocyanin compounds }\end{array}$} & \multicolumn{6}{|c|}{ Phenolic and anthocyanin compounds ${ }^{z}$} & \multirow{2}{*}{$\begin{array}{c}\text { Antioxidant } \\
\text { capacity }\end{array}$} & \multirow[b]{2}{*}{ SPC } \\
\hline & $1^{z}$ & 2 & 3 & 4 & 5 & 6 & & \\
\hline$\overline{1}$ & 1 & 0.85 & 0.90 & 0.90 & 0.97 & 0.91 & 0.95 & 0.94 \\
\hline 2 & 0.85 & 1 & 0.90 & 0.94 & 0.85 & 0.80 & 0.86 & 0.89 \\
\hline 4 & 0.90 & 0.94 & 0.93 & 1 & 0.90 & 0.78 & 0.91 & 0.93 \\
\hline 5 & 0.97 & 0.85 & 0.90 & 0.90 & 1 & 0.92 & 0.97 & 0.94 \\
\hline 6 & 0.91 & 0.80 & 0.81 & 0.78 & 0.92 & 1 & 0.85 & 0.85 \\
\hline SPC & 0.94 & 0.89 & 0.93 & 0.93 & 0.94 & 0.85 & 0.96 & 1 \\
\hline
\end{tabular}

${ }_{\mathrm{z}} 1$ = chlorogenic acid; 2 = neochlorogenic acid; 3 = catechin; 4 = caffeic acid; 5 = cyanidin 3 -glucoside; $6=$ cyanidin 3 -rutinoside.

and control peels, respectively). In the pulp, no differences among irrigation treatments were found at day 0 . There was a decreasing tendency in all the samples and in all conditions, with $\mathrm{RDI}_{2}$ being the treatment that obtained the highest final APX activity either in peel or pulp (Fig. 7).

\section{Discussion}

Environmental factors play a stimulating role in the synthesis and accumulation of useful phytochemicals in fruit. Besides, their role on moderating stress, provoked by controlled drought, appears promising (Poiroux-Gonord et al., 2010). However, how long should the stress be applied to obtain a response? Is it possible to succeed with extra-early cultivars? It is well known that CAT activity can vary due to duration and intensity of the stress (Allen et al., 2010; Chaparzadeh et al., 2004; Mitchell et al., 2013). This fact was observed in this extra-early nectarine cultivar showing differences in CAT activity levels between $\mathrm{RDI}_{1}$ and $\mathrm{RDI}_{2}$ treatments (Fig. 4). This difference was a good indicator of water stress clearly distinguishable among the three irrigation treatments. Although the water stress integral was low due to the short period of time available between blooming and harvest (February-April), changes in CAT demonstrate that early nectarine tree and fruit can detect and acclimate to water stress.

In this work, we observed a strong influence of water also on SPC. Nectarine fruit from RDI treatments contained more SPC that did the control treatment. Previous authors have shown water stress increasing polyphenol content in grape (Vitis vinifera L.) cultivar Merlot (Peterlunger et al., 2005), olive (Olea europaea L.; Gómez-Rico et al., 2006), tomato (Solanum lycopersicum L.; Barbagallo et al., 2013), and nectarine (Thakur and Singh, 2013). Biosynthesis of phenolic compounds can be stimulated by abiotic stresses such as water stress, with drought shown to bring the accumulation of ROS such as superoxide, hydrogen peroxide, and hydroxyl radicals (Hasegawa et al., 2000). These ROS may be signals that induce ROS scavengers such as phenolic compounds, leading to an increase in phenolic concentrations due to the activation of synthetic metabolic pathways (Xiong et al., 2002). The higher SPC on the initial evaluation could be attributed to the activation of the PAL metabolic pathway due to stress conditions ( $\mathrm{Oh}$ et al., 2009), which was higher at harvest in RDI fruit and increased, in all irrigation treatments, during cold storage (Fig. 6). This postharvest increase could be explained by the increase in PAL activity under a chilling stress such as cold storage (Guo et al., 2008; Sánchez-Ballesta et al., 2000) working as a biological marker in a defense-related enzyme group (Lafuente et al., 2003; Spadoni et al., 2014). This circumstance could help RDI nectarine fruit in maintaining their initial phenolic concentration level (Table 2). In addition, PAL is the first enzyme that is active in the synthesis of phenols through the shikimic pathway, producing trans-cinnamic acid. This acid is converted to intermediate products such as coumaric acid, sinapic acid, and so on that can then turn into chlorogenic acid, coumarin, and so on, to finally obtain flavonoids, among other compounds (Dokhanieh et al., 2013; Kim et al., 2004). In connection with this, the behavior of individual polyphenols was quite similar to the changes in SPC. Indeed, the average correlation coefficient between individual compounds and SPC was 0.91 (Table 3). The sum of the levels obtained in pulp and peel for each polyphenol showed that chlorogenic acid was the most abundant, followed by neochlorogenic acid, its isomer. This was consistent with results obtained in different nectarine cultivars (Scattino et al., 2014), with chlorogenic acid being the most abundant polyphenol in peach and nectarine fruit. Nectarine fruit under RDI showed changes in caffeic acid content that followed the trend described for chlorogenic acid, but in lower concentrations. These two compounds are linked because chlorogenic acid is the ester that is formed with caffeic acid and L-quinic acid (3-O-caffeoyl-D-quinic acid) (Clifford, 1999; Forino et al., 2015).

The flavanol concentration results showed that RDI treatments had a higher concentration of catechin in the peel. However, these treatments as well as control suffered a decrease during storage and retail sale period due to their oxidation, probably caused by the increase of PPO levels in those same periods (Fig. 5). Hofrichter and Ullrich (2014) proposed flavanols as the major substrates for enzymatic oxidation. This was mainly observed in control nectarine fruit that had a higher PPO activity and hence a lower concentration of flavanols. In fact, the correlation between PPO activity and SPC was 0.70 , as shown by a decrease in the substrates (phenolics) due to the increase in PPO activity. PPO activity was higher in pulp than in peel, unlike the rest of responses. This meant that the loss of integrity and permeability of the cell membrane was more pronounced in pulp, granting PPO an easier access to phenolic substrates, increasing its activity through SPC oxidation. The 
reason why this oxidative reaction was more intense in pulp was because pulp contained less pectins in the cell membrane than peel, which act as stabilizers and thickeners (Liaotrakoon et al., 2013).

In the case of cyanidin 3-glucoside and cyanidin 3-rutinoside, the difference between both tissues was even higher, as these compounds were not detected in pulp. The lack of anthocyanins was also reported in different cultivars by others authors (Abe et al., 2012; Guo et al., 2003; Tomás-Barberán et al., 2001). No anthocyanins were found in the pulp, because this group of flavonoids is usually located in the epidermal cells (Agati et al., 2012). They are responsible for the fruit's color (Markakis, 2012), so it is common not to find them in a white pulp nectarine fruit such as 'VioWhite 5'. In the case of peel, a greater accumulation of these anthocyanins in the nectarine fruit subjected to water stress was observed. Some works have also found an increase in total anthocyanins of apricot [Prunus armeniaca (L.) Huth], grape, and pomegranate (Punica granatum L.) fruit due to RDI (Buendía et al., 2008; Laribi et al., 2013; Peña et al., 2013; Tarara and Pérez-Peña, 2015). The expression of some of the genes responsible for anthocyanin synthesis has been reported to be significantly increased by water deficits (Deluc et al., 2009). In our experiment, most of the treatments suffered a general decreasing trend in anthocyanin concentration with storage time, in particular, under retail period. This decrease during storage was also found in pomegranate under RDI as reported by Laribi et al. (2013), who also reported the high susceptibility of anthocyanins to enzymatic oxidation after very prolonged cold storage by the loss of cellular compartmentalization. This hypothesis agrees with findings of a study on the peel of litchi (Litchi chinensis Sonn.; Zhang et al., 2000).

Antioxidant activity generally decreased with the reduction of the SPC, whereas PPO activity increased, oxidizing some of these compounds. Control samples showed the highest PPO activity, which meant lower antioxidant activity, while RDI samples, especially $\mathrm{RDI}_{2}$, and in peel tissue maintained a higher antioxidant activity at harvest and during storage. The existence of a high concentration of phenolic compounds in RDI nectarine fruit led to higher antioxidant activity, as these substances are responsible for the antioxidant activity in most plant tissues (Arion et al., 2014). In potato (Solanun tuberosum L.) cultivars, drought conditions have been showed to increase oxidative stress, which could be responsible for the rise in total antioxidant content (Andre et al., 2009). Research by Jovanovic et al. (2010) in potato and Peña et al. (2013) in pomegranate also found increased antioxidant content using deficit irrigation as compared with fully irrigated plants.

The results on the concentration of vitamin $\mathrm{C}$ showed that nectarine fruit from RDI had an initial higher vitamin $\mathrm{C}$ with lower AsA content but much higher DHA content, with the difference being more pronounced in the $\mathrm{RD}_{2}$ treatment (Fig. 3). An opposite response was found in control nectarine fruit. The results showed that the level of water stress affected the oxidation of AsA into DHA, activating the APX enzyme (Fig. 7). In control nectarine fruit, a higher content of AsA compared with DHA content was found, which implies a negative correlation between these two responses. However, this correlation is not obvious because the reaction is reversible, so it is possible to have both processes active at the same time. This can see in the higher APX activity in fruit subjected to RDI strategies. The observed decreasing trend in all treatments with cold storage and retail sale period could be a result of ripening and senescence (Gautier et al., 2008; Kalt, 2005).

\section{Conclusions}

The results of this research work confirm the existence of water stress when RDI is applied on extra-early nectarine. The effect of applying RDI induced a change on enzymes studied depending on the intensity and duration of water stress. In this sense, RDI fruit, especially $\mathrm{RDI}_{2}$, presented higher CAT, PAL, and APX enzymes activity and, together with the DHA level, appeared as indicators of this abiotic stress. RDI nectarine fruit had an increased in SPC and flavonoid contents improving the nutraceutical quality of the product. With storage, PPO increased its activity, leading to a reduction of flavonoids, particularly in pulp. In this study, $\mathrm{RDI}_{2}$ achieved the highest initial and stored values of antioxidant capacity. The peel, as opposed to the pulp, was the main tissue where bioactive compounds of 'VioWhite 5' nectarine fruit were found. The significant water savings was of 780 and $2050 \mathrm{~m}^{3} \cdot \mathrm{ha}^{-1}$ per year for $\mathrm{RDI}_{1}$ and $\mathrm{RDI}_{2}$, respectively. Management of water stress by the application of RDI strategies can promote bioactive compounds on extra-early nectarine and contribute to reduce water demand.

\section{Literature Cited}

Abe, L.T., F.M. Lajolo, and M.I. Genovese. 2012. Potential dietary sources of ellagic acid and other antioxidants among fruits consumed in Brazil: Jabuticaba (Myrciaria jaboticaba (Vell.) Berg). J. Sci. Food Agr. 92:1679-1687.

Abrisqueta, I., L.M. Tapia, W. Conejero, M.I. Sánchez-Toribio, J.M. Abrisqueta, J. Vera, and M.C. Ruiz-Sánchez. 2010. Response of early-peach [Prunus persica (L.)] trees to deficit irrigation. Span. J. Agr. Res. 8:30-39.

Agati, G., E. Azzarello, S. Pollastri, and M. Tattini. 2012. Flavonoids as antioxidants in plants: Location and functional significance. Plant Sci. 196:67-76.

Alcobendas, R., J.M. Mirás-Avalos, J.J. Alarcón, F. Pedrero, and E. Nicolás. 2012. Combined effects of irrigation, crop load and fruit position on size, color and firmness of fruits in an extra-early cultivar of peach. Sci. Hort. 142:128-135.

Allen, C.D., A.K. Macalady, H. Chenchouni, D. Bachelet, N. McDowell, M. Vennetier, T. Kitzberger, A. Rigling, D.D. Breshears, E.H. Hogg, P. González, R. Fensham, Z. Zhang, J. Castro, N. Demidova, J.H. Lim, G. Allard, S.W. Running, A. Semerci, and N. Cobb. 2010. A global overview of drought and heat-induced tree mortality reveals emerging climate change risks for forests. For. Ecol. Mgt. 259:660-684.

Allen, R.G., L.S. Pereira, D. Raes, and M. Smith. 1998. Crop evapotranspiration. Guidelines for computing crop water requirements. FAO Irr. Drainage Paper No. 56.

Andre, C.M., R. Schafleitner, C. Guignard, M. Oufir, C.A. AlvaradoAliaga, G. Nomberto, L. Hoffmann, J.F. Hausman, D. Evers, and Y. Larondelle. 2009. Modification of the health-promoting value of potato tubers field grown under drought stress: Emphasis on dietary antioxidant and glycoalkaloid contents in five native Andean cultivars (Solanum tuberosum L.). J. Agr. Food Chem. 57:599-609.

Arion, C.M., J. Tabart, C. Kevers, M. Niculaua, R. Filimon, D. Beceanu, and J. Dommes. 2014. Antioxidant potential of different plum cultivars during storage. Food Chem. 146:485-491.

Artés-Hernández, F., F.A. Tomas-Barberán, and F. Artés. 2006. Modified atmosphere packaging preserves quality of $\mathrm{SO}_{2}$-free 'Superior seedless' table grapes. Postharvest Biol. Technol. 39:146-154.

Barbagallo, R.N., I. Di Silvestro, and C. Patanè. 2013. Yield, physicochemical traits, antioxidant pattern, polyphenol oxidase 
activity and total visual quality of field-grown processing tomato $\mathrm{cv}$. Brigade as affected by water stress in Mediterranean climate. J. Sci. Food Agr. 93:1449-1457.

Benzie, I.F. and J.J. Strain. 1996. The ferric reducing ability of plasma (FRAP) as a measure of 'antioxidant power': The FRAP assay. Anal. Biochem. 239:70-76.

Boeing, H., A. Bechthold, A. Bub, S. Ellinger, D. Haller, H. Oberritter, M. Schulze, P. Stehle, and B. Watzl. 2012. Critical review: Vegetables and fruit in the prevention of chronic diseases. Eur. J. Nutr. 51:637-663.

Bradford, M.M. 1976. A rapid and sensitive method for the quantitation of microgram quantities of protein utilizing the principle of protein-dye binding. Anal. Biochem. 72:248-254.

Buendía, B., A. Allende, E. Nicolás, J.J. Alarcón, and M.I. Gil. 2008. Effect of regulated deficit irrigation and crop load on the antioxidant compounds of peaches. J. Agr. Food Chem. 56:3601-3608.

Cabezas-Serrano, A.B., M.I. Amodio, R. Cornacchia, R. Rinaldi, and G. Colelli. 2009. Suitability of five different potato cultivars (Solanum tuberosum L.) to be processed as fresh-cut products. Postharvest Biol. Technol. 53:138-144.

Chalmers, D.J., P.D. Mitchell, and L. Van Heek. 1981. Control of peach tree growth and productivity by regulated water supply, tree density, and summer pruning. J. Amer. Soc. Hort. Sci. 106:307-312. Chaparzadeh, N., M.L. Amico, R.K. Nejad, R. Izzo, and F.N. Izzo. 2004. Antioxidative responses of Calendula officinalis under salinity conditions. Plant Physiol. Biochem. 42:695-701.

Clifford, M.N. 1999. Chlorogenic acids and other cinnamatesNature, occurrence and dietary burden. J. Sci. Food Agr. 79:362-372. Crisosto, C.H., R.S. Johnson, J.G. Luza, and G.M. Crisosto. 1994. Irrigation regimes affect fruit soluble solids concentration and rate of water loss of 'O'Henry' peaches. HortScience 29:1169-1171.

de Carvalho, M.H.C. 2013. Drought stress and reactive oxygen species. Production, scavenging and signaling. Plant Signal. Behav. 3:156-165.

Deluc, L.G., D.R. Quilici, A. Decendit, J. Grimplet, M.D. Wheatley, K.A. Schlauch, J.M. Merillon, J.C. Cushman, and G.R. Cramer. 2009. Water deficit alters differentially metabolic pathways affecting important flavor and quality traits in grape berries of Cabernet Sauvignon and Chardonnay. BMC Genomics 10:212.

Dokhanieh, A.Y., M.S. Aghdam, J.R. Fard, and H. Hassanpour. 2013. Postharvest salicylic acid treatment enhances antioxidant potential of cornelian cherry fruit. Sci. Hort. 154:31-36.

Domínguez, A., J.A. De Juan, J.M. Tarjuelo, R.S. Martínez, and A. Martínez-Romero. 2012. Determination of optimal regulated deficit irrigation strategies for maize in a semi-arid environment. Agr. Water Mgt. 110:67-77.

Falagán, N., F. Artés, F. Artés-Hernández, P.A. Gómez, A. PérezPastor, and E. Aguayo. 2015. Comparative study on postharvest performance of nectarines grown under regulated deficit irrigation. Postharvest Biol. Technol. 110:24-32.

Falagán, N., F. Artés, P.A. Gómez, F. Artés-Hernández, W. Conejero, and E. Aguayo. 2014. Deficit irrigation strategies combined with controlled atmosphere preserve quality in early peaches. Food Sci. Technol. (Campinas.) 21:547-556.

Falguera, V., J. Lordan, F. Gatius, M. Pascual, J.M. Villar, A. Ibarz, and J. Rufat. 2012. Influence of nitrogen fertilization on polyphenol oxidase activity in peach fruits. Sci. Hort. 142:155-157.

Forino, M., G.C. Tenore, L. Tartaglione, E. Novellino, and P. Ciminiello. 2015. (1S, 3R, 4S, 5R) 5-O-Caffeoylquinic acid: Isolation, stereo-structure characterization and biological activity. Food Chem. 178:306-310.

García-Parra, J., F. González-Cebrino, J. Delgado, M. Lozano, T. Hernández, and R. Ramírez. 2011. Effect of thermal and highpressure processing on the nutritional value and quality attributes of a nectarine puree with industrial origin during the refrigerated storage. J. Food Sci. 76:618-625.

Gautier, H., V. Diakou-Verdin, C. Bénard, M. Reich, M. Buret, F. Bourgaud, J.L. Poëssel, C. Caris-Veyrat, and M. Génard. 2008. How does tomato quality (sugar, acid, and nutritional quality) vary with ripening stage, temperature, and irradiance? J. Agr. Food Chem. $56: 1241-1250$.

Goldhamer, D.A. 1989. Drought irrigation strategies for deciduous orchards. Univ. California, Div. Agr. Natural Resources, Coop. Ext. Publ. No. 21453.

Gómez-Rico, A., M.D. Salvador, M. La Greca, and G. Fregapane. 2006. Phenolic and volatile compounds of extra virgin olive oil (Olea europaea L. cv. Cornicabra) with regard to fruit ripening and irrigation management. J. Agr. Food Chem. 54:7130-7136.

Guo, C., J. Yang, J. Wei, Y. Li, J. Xu, and Y. Jiang. 2003. Antioxidant activities of peel, pulp and seed fractions of common fruits as determined by FRAP assay. Nutr. Res. 23:1719-1726.

Guo, J., W. Han, and M. Wang. 2008. Ultraviolet and environmental stresses involved in the induction and regulation of anthocyanin biosynthesis: A review. Afr. J. Biotechnol. 7:4966-4972.

Hasegawa, P.M., R.A. Bressan, J.K. Zhu, and H.J. Bohnert. 2000. Plant cellular and molecular responses to high salinity. Plant Physiol. Biochem. 51:463-499.

Hofrichter, M. and R. Ullrich. 2014. Oxidations catalyzed by fungal peroxygenases. Curr. Opin. Chem. Biol. 19:116-125.

Hsiao, T.C. 1990. Measurements of plant water status, p. 243-279. In: B.A. Stewart and D.A. Nielsen (eds.). Irrigation of agricultural crops. Amer. Soc. Agron., Madison, WI.

Iglesias, A., L. Garrote, F. Flores, and M. Moneo. 2007. Challenges to manage the risk of water scarcity and climate change in the Mediterranean. Water Resources Mgt. 21:775-788.

Iglesias, I. 2012. Producción, consumo e innovación varietal en el melocotón. Alimentación equipos y tecnología 268:25-31.

Jovanovic, Z., R. Stikic, B. Vucelic-Radovic, M. Paukovic, Z. Brocic, G. Matovic, S. Rovcanin, and M. Mojevic. 2010. Partial root-zone drying increases WUE, $\mathrm{N}$ and antioxidant content in field potatoes. Eur. J. Agron. 33:124-131.

Kalt, W. 2005. Effects of production and processing factors on major fruit and vegetable antioxidants. J. Food Sci. 70:11-19.

Katerji, N., M. Mastrorilli, and G. Rana. 2008. Water use efficiency of crops cultivated in the Mediterranean region: Review and analysis. Eur. J. Agron. 28:493-507.

Ke, D. and M.E. Saltveit. 1986. Effects of calcium and auxin on russet spotting and phenylalanine ammonia-lyase activity in iceberg lettuce. HortScience 21:1169-1171.

Kim, S.L., S.K. Kim, and C.H. Park. 2004. Introduction and nutritional evaluation of buckwheat sprouts as a new vegetable. Food Res. Intl. 37:319-327.

Lafuente, M.T., L. Zacarías, M.A. Martı̀nez-Téllez, M.T. SánchezBallesta, and A. Granell. 2003. Phenylalanine ammonia-lyase and ethylene in relation to chilling injury as affected by fruit age in citrus. Postharvest Biol. Technol. 29:309-318.

Laribi, A.I., L. Palou, D.S. Intrigliolo, P.A. Nortes, C. Rojas-Argudo, V. Taberner, J. Bartual, and M.B. Pérez-Gago. 2013. Effect of sustained and regulated deficit irrigation on fruit quality of pomegranate cv. 'Mollar de Elche' at harvest and during cold storage. Agr. Water Mgt. 125:61-70.

Legua, L., J. Pinochet, M.A. Moreno, J.J. Martínez, and F. Hernández. 2012. Prunus hybrids rootstocks for flat peach. Scientia Agr. 69:13-18. Liaotrakoon, W., S. Van Buggenhout, S. Christiaens, K. Houben, N. De Clercq, K. Dewettinck, and M.E. Hendrickx. 2013. An explorative study on the cell wall polysaccharides in the pulp and peel of dragon fruits (Hylocereus spp.). Eur. Food Res. Technol. 237:341351.

Maasland, D.H., P.A. Van den Brandt, B. Kremer, R.A. Goldbohm, and L.J. Schouten. 2015. Consumption of vegetables and fruits and risk of subtypes of head-neck cancer in the Netherlands Cohort Study. Intl. J. Cancer 136:396-409.

Markakis, P. 2012. Anthocyanins as food colors. Academic Press, New York, NY. 
Miller, G., N. Suzuki, S. Ciftci-Yilmaz, and R. Mittler. 2010. Reactive oxygen species homeostasis and signalling during drought and salinity stresses. Plant Cell Environ. 33:453-467.

Mitchell, P.J., A.P. O'Grady, D.T. Tissue, D.A. White, M.L. Ottenschlaeger, and E.A. Pinkard. 2013. Drought response strategies define the relative contributions of hydraulic dysfunction and carbohydrate depletion during tree mortality. New Phytol. 197:862-872.

Mpelasoka, B.S., M.H. Behboudian, and T.M. Mills. 2001. Effects of deficit irrigation on fruit maturity and quality of 'Braeburn' apple. Sci. Hort. 90:279-290.

Myers, B.J. 1988. Water stress integral—A link between short-term stress and long-term growth. Tree Physiol. 4:315-323.

Nakano, Y. and K. Asada. 1981. Hydrogen peroxide is scavenged by ascorbate-specific peroxidase in spinach chloroplasts. Plant Cell Physiol. 22:867-880.

Noctor, G., A. Mhamdi, and C.H. Foyer. 2014. The roles of reactive oxygen metabolism in drought: Not so cut and dried. Plant Physiol. 164:1636-1648.

Oh, M.M., H.N. Trick, and C.B. Rajashekar. 2009. Secondary metabolism and antioxidants are involved in environmental adaptation and stress tolerance in lettuce. J. Plant Physiol. 166:180-191.

Peña, M.E., F. Artés-Hernández, E. Aguayo, G.B. Martínez-Hernández, A. Galindo, F. Artés, and P.A. Gómez. 2013. Effect of sustained deficit irrigation on physicochemical properties, bioactive compounds and postharvest life of pomegranate fruit (cv. 'Mollar de Elche'). Postharvest Biol. Technol. 86:171-180.

Pérez-Pastor, A., M.C. Ruiz-Sánchez, J.A. Martínez, P.A. Nortes, F. Artés, and R. Domingo. 2007. Effect of deficit irrigation on apricot fruit quality at harvest and during storage. J. Sci. Food Agr. 87:2409-2415.

Peterlunger, E., P. Sivilotti, and V. Colussi. 2005. Water stress increased polyphenolic quality in 'Merlot' grapes. Acta Hort. 689:293-300.

Poiroux-Gonord, F., L.P. Bidel, A.L. Fanciullino, H. Gautier, F. LauriLópez, and L. Urban. 2010. Health benefits of vitamins and secondary metabolites of fruits and vegetables and prospects to increase their concentrations by agronomic approaches. J. Agr. Food Chem. 58:12065-12082.

Sánchez-Ballesta, M.T., M.T. Lafuente, L. Zacarías, and A. Granell. 2000. Involvement of phenylalanine ammonia-lyase in the response of Fortune mandarin fruits to cold temperature. Physiol. Plant. 108:382-389.

Scattino, C., A. Castagna, S. Neugart, H.M. Chan, M. Schreiner, C.H. Crisosto, and A. Ranieri. 2014. Post-harvest UV-B irradiation induces changes of phenol contents and corresponding biosynthetic gene expression in peaches and nectarines. Food Chem. 163:51-60.
Silveira, A.C., E. Aguayo, and F. Artés. 2013. The suitability of three Galia melon cultivars and different types of cuts for the fresh-cut industry. J. Sci. Food Agr. 93:3826-3831.

Sotiropoulos, T., D. Kalfountzos, I. Aleksiou, S. Kotsopoulos, and N. Koutinas. 2010. Response of a clingstone peach cultivar to regulated deficit irrigation. Scientia Agr. 67:164-169.

Spadoni, A., M. Guidarelli, S.M. Sanzani, A. Ippolito, and M. Mari. 2014. Influence of hot water treatment on brown rot of peach and rapid fruit response to heat stress. Postharvest Biol. Technol. 94:66-73.

Swain, T. and W.E. Hillis. 1959. The phenolic constituents of Prunus domestica. I.-The quantitative analysis of phenolic constituents. J. Sci. Food Agr. 10:63-68.

Tarara, J.M. and J.E. Pérez-Peña. 2015. Moderate water stress from regulated deficit irrigation decreases transpiration similarly to net carbon exchange in grapevine canopies. J. Amer. Soc. Hort. Sci. 140:413-426.

Thakur, A. and Z. Singh. 2012. Responses of 'Spring Bright' and 'Summer Bright' nectarines to deficit irrigation: Fruit growth and concentration of sugars and organic acids. Sci. Hort. 135:112-119.

Thakur, A. and Z. Singh. 2013. Deficit irrigation in nectarine: Fruit quality, return bloom and incidence of double fruits. European J. Hort. Sci. 78:67-75.

Tomás-Barberán, F.A., M.I. Gil, P. Cremin, A.L. Waterhouse, B. HessPierce, and A.A. Kader. 2001. HPLC-DAD-ESIMS analysis of phenolic compounds in nectarines, peaches, and plums. J. Agr. Food Chem. 49:4748-4760.

Urban, L., M. Staudt, J. Ripoll, F. Lauri-López, and N. Bertin. 2014. Less can make more-Revisiting fleshy fruit quality and irrigation in horticulture. Chron. Hort. 54:25-30.

Vizzotto, M., W. Porter, D. Byrne, and L. Cisneros-Zevallos. 2014. Polyphenols of selected peach and plum genotypes reduce cell viability and inhibit proliferation of breast cancer cells while not affecting normal cells. Food Chem. 164:363-370.

Wang, Y.S., S.P. Tian, and Y. Xu. 2005. Effects of high oxygen concentration on pro- and anti-oxidant enzymes in peach fruits during postharvest periods. Food Chem. 91:99-104.

Xiong, L., K.S. Schumaker, and J.K. Zhu. 2002. Cell signaling during cold, drought, and salt stress. Plant Cell 14:165-183.

Zhang, D., P.C. Quantick, and J.M. Grigor. 2000. Changes in phenolic compounds in litchi (Litchi chinensis Sonn.) fruit during postharvest storage. Postharvest Biol. Technol. 19:165172. 